\title{
СЕЛЕКЦИЯ ИНБРЕДНЫХ ЛИНИЙ ОЗИМОЙ РЖИ (Secale cereale L.) НА ОБЩУЮ И СПЕЦИФИЧЕСКУЮ КОМБИНАЦИОННУЮ СПОСОБНОСТЬ И ЕЕ СВЯЗЬ С СЕЛЕКЦИОННЫМИ ПРИЗНАКАМИ
}

\author{
А.А. ГОНЧАРЕНКО, А.В. МАКАРОВ, С.А. ЕРМАКОВ, Т.В. СЕМЕНОВА, \\ В.Н. ТОЧИЛИН, Н.В. ЦЫГАНКОВА, О.А. КРАХМАЛЕВА
}

Получение гетерозисных гибридов $\mathrm{F}_{1}$ взамен сортов-популяций - одно из значительных достижений в селекции XX века. Рожь (Secale cereale L.) как строго перекрестно-опыляемая культура весьма перспективна для гетерозисной селекции. Успешность гибридной селекции ржи зависит от наличия гомозиготных линий с высокой комбинационной способностью. Скрещивание линий по схеме топкросса позволяет эффективно выявлять и использовать для синтеза высокогетерозисных гибридов только лучшие генотипы. В представленной работе впервые охарактеризованы уникальные высокогомозиготные инбредные линии озимой ржи, полученные на основе трех российских генопулов, и выявлены линии с высокой комбинационной способностью, перспективные для селекции на продуктивность и качество. Цель наших исследований заключалась в оценке общей и специфическую комбинационной способности инбредных линий озимой ржи с помощью метода полных топкроссов. Тестовые скрещивания по этой схеме провели в 2016 году на изолированных участках, где материнской формой послужили 5 стерильных линий с цитоплазмой типа Пампа (Н-649, Н-577, Н-842, Н-1058 и Н-1185), а отцовской - 4 мужски фертильные линии (Н-451, Н-1011, Н-1247 и Н-1071), которые были тестерами. Всего получили 20 простых межлинейных гибридов $F_{1}$. Их испытание провели в 2017 году на делянках площадью 8,0 м² в 3 по-

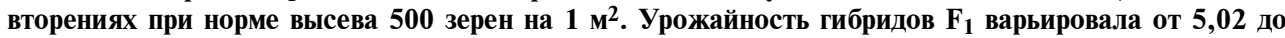
7,90 т/га при аналогичном показателе у популяционного сорта Валдай 6,50 т/га. Наиболее продуктивным оказался гибрид $\mathrm{F}_{1}$ (H-649 × H-1011), который при урожайности 7,9 т/га превысил стандарт Валдай на $21,5 \%(P \geq 0,95)$. В целом по опыту частота гибридов $F_{1}$ с достоверно высоким конкурсным гетерозисом составила 7 из 20 (или $35 \%$ ). Основной причиной варьирования урожайности у гибридов $F_{1}$ стали различия их родительских форм по комбинационной способности. В дисперсию признака урожайности существенный вклад вносили как общая (ОКС), так и специфическая (СKC) комбинационная способность линий, однако на долю эффектов ОКС приходилось 91,1 \% всей изменчивости урожайности, а на СКС - только 7,7 \%. Из этого следует, что основной компонент генотипической вариансы признака урожайности - аддитивное взаимодействие генов, но не внутрилокусное доминирование. В то же время высокое соотношение варианс ОКС/СКС указывает на весьма значительную генетическую дивергенцию инбредных линий, взятых для скрещивания. Достоверно высокую ОКС имели стерильные аналоги линий Н-1185 и Н-649, а также отцовская линия-тестер Н-1011. Существенно более низкой общей комбинационной способностью обладали короткостебельные линии Н-577 и Н-1071. Высокие эффекты СКС показали стерильные линии Н-1058 и Н-649, а также тестеры Н-1071 и Н-451. Выявлена положительная корреляция между оценками ОКС линий и высотой растений $(r=0,85 \pm 0,10)$, массой 1000 зерен $(r=0,80 \pm 0,13)$ и массой зерна с колоса $(r=0,64 \pm 0,21)$. Полученные результаты свидетельствуют о важном значении селекции инбредных линий озимой ржи на высокую продуктивность и положительную сочетаемость признаков крупнозерности и короткостебельности.

Ключевые слова: озимая рожь, цитоплазматическая мужская стерильность, ЦМС, тестер, гомозиготная линия, $F_{1}$ гибриды, общая и специфическая комбинационная способность, ОКС и СКС, урожайность, масса 1000 зерен, масса зерна с колоса, короткостебельность.

Выбор родительских форм для скрещивания составляет фундаментальную проблему в селекции гибридов $\mathrm{F}_{1}$ озимой ржи на основе цитоплазматической мужской стерильности (ЦМС). Четкое доказательство наличия цитоплазматической мужской стерильности у аргентинского сорта ржи Пампа представили H.H. Geiger и F.W. Schnell (Гогенгеймский университет - Universität Hohenheim, Германия) (1), а испытание первых экспериментальных гибридов $\mathrm{F}_{1}$ дало впечатляющие результаты. По сравнению с родительскими линиями средний гетерозис по урожаю зерна составлял $39 \%$, по числу зерен в колосе - 58 \%, по массе 1000 зерен - $37 \%$, по высоте растения - $31 \%$, по числу колосьев на $1 \mathrm{~m}^{2}-10 \%$ (2). Это по-

* Исследования выполнены при поддержке РФФИ в рамках научного проекта № 17-44-500827. 
служило стимулом для частных инвестиций в методологию, биотехнологию и практическую селекцию гибридной ржи, в результате чего ее доля в структуре мировых посевов этой культуры превысила 20 \% (3). В последние годы немецкими селекционными компаниями создана серия усовершенствованных гибридов, сочетающих высокую урожайность с другими ценными признаками (короткостебельностью, устойчивостью к полеганию, бурой ржавчине и спорынье) при улучшении хлебопекарных качеств зерна и большей пригодности для производства кормов и биогаза (4).

B среднем урожай зерна у гибридов $\mathrm{F}_{1}$ озимой ржи на 15-20\% выше, чем у популяционных сортов (5). В Германии с 1982 по 2005 год годовой прирост урожайности у сортов-популяций составил 30 кг/га, у гибридных сортов - 51 кг/га (на 70 \% выше) (6). При этом темпы селекционного улучшения на гибридном уровне значительно выше, чем на популяционном. Так, в Германии где за 26 лет (1991-2016 годы) урожайность гибридов ржи в опытах государственного испытания увеличилась на 23,3\%, тогда как сортов-популяций - на 18,1 \% (4). В Польше в системе государственного испытания прибавка урожая таких сортов по сравнению с популяционными варьировала от 9,8 до 14,5 ц/га, при этом гибриды $\mathrm{F}_{1}$ были устойчивее к полеганию и меньше поражались бурой ржавчиной и мучнистой росой (7). В Канаде в областях традиционного выращивания этой культуры продолжавшееся длительное время уменьшение ее площадей приостановилось благодаря интродукции европейских гибридных сортов (8). В Государственный реестр селекционных достижений Российской Федерации внесены пять гибридов ржи немецкой селекции - Пикассо (Picasso), KBC Магнифико (Magnifico), Палаццо (Palazzo), KBC PABO (KWS PABO) (оригинатор «KWS Lochow GmbH», Германия); Хеллтоп (Helltop) (оригинатор «Monsanto Saaten GmbH», Германия) и два украинских гибрида (Первисток и Юрьевец, оригинатор Институт растениеводства им. В.Я. Юрьева, Украина), но площади под ними пока невелики; отечественные линейные гибриды в реестре отсутствуют. Гетерозисная селекция ржи на основе ЦМС в России в настоящее время практически не ведется. Исключение составляют работы на основе трех генопулов ржи (немчиновского, саратовского и кировского) с применением многократного инцухта растений из самофертильных популяций и насыщающих скрещиваний для получения с использованием ЦМС стерильных аналогов линий типа Пампа (9) и последующей гибридной селекции (Федеральный исследовательский центр «Немчиновка»).

Оценка генетических свойств гомозиготных линий с высокой собственной продуктивностью в межлинейных скрещиваниях - наиболее сложный и затратный этап при гетерозисной селекции. Определение общей комбинационной способности (ОKC) предлагается начинать в первых поколениях инбридинга $\left(\mathrm{I}_{1}-\mathrm{I}_{3}\right)$, так как в последующих вероятность расщепления линий по этому признаку весьма невелика, и их целесообразно исключить из дальнейшего испытания и самоопыления (10). Это особенно важно, так как частота линий с высокой ОКС очень низкая. Так, из 364 гибридных комбинаций в различных типах скрещиваний (поликроссные, топкроссные, сортолинейные, межлинейные) такие линии составляли около $20 \%$ (11), а при учете только экономически значимого гетерозиса - менее $8 \%$ (12). Причина в том, что те инбредные линии, которые превосходят другие линии, могут быть генетически родственны, из-за чего эффект гетерозиса снижается. Максимальный гетерозис обеспечивается только при скрещивании генетически неодинаковых инбредных линий (13).

Объективную оценку комбинационной способности родительских линий дает анализ гибридов $\mathrm{F}_{1}$ от диаллельных скрещиваний. В то же 
время если с одним сортом-тестером можно определить ОКС родительских форм, то схема, в которой тестером служит набор селекционно ценных инбредных линий, позволяет охарактеризовать их СКС без диаллельного скрещивания (14). Изучение пяти инбредных линий кукурузы в качестве тестеров показало (15), что лучшими в этом случае будут формы с повышенной урожайностью и высокими эффектами ОКС. Топкросс как метод ранней диагностики считается эффективным приемом оценки комбинационной способности у линий озимой ржи (16). Важно учитывать, что на выбор оптимального числа тестеров при определении ОКС в значительной степени влияет число точек экологического испытания тесткроссов (17).

ОКС инбредных линий используют при отборе не только по урожайности, но и по другим признакам. Сравнение 40 простых межлинейных гибридов озимой ржи в условиях искусственного заражения грибом Fusarium culmorum (W.G. Sm.) Sacc. показало, что варианса OKC по устойчивости к этому патогену была в 10 раз выше вариансы СКС (18). На этом основании было сделано заключение о преобладании аддитивного взаимодействия генов, определяющих устойчивость, что определило стратегию селекции. Сходные данные получены по озимой тритикале (19): здесь также установлена тесная связь между эффектами ОКС родителей и их собственной продуктивностью, что дает возможность надежно определять ожидаемую устойчивость к фузариозу колоса в $\mathrm{F}_{1}$.

Несомненный интерес представляет прогноз гибридной мощности у межлинейных гибридов. Он возможен как на основе эффектов ОКС, так и по данным о продуктивности инбредных линий per se (20). Наиболее удобны для этого структурно простые признаки, по средней величине которых у родительских линий можно ориентировочно судить об ожидаемой экспрессии этих признаков у гибридов. В отношении структурно сложных признаков, например урожайности, точность такого прогнозирования снижается из-за эффектов доминирования (21).

В представленной работе нами впервые охарактеризованы уникальные высокогомозиготные инбредные линии озимой ржи, которые были получены на основе трех отечественных генопулов, и выявлены формы с высокой комбинационной способностью, перспективные для селекции на продуктивность и другие основные хозяйственно ценные признаки (зимостойкость, короткостебельность, масса 1000 зерен и т.д.).

Цель исследований - определить комбинационную способность инбредных линий озимой ржи с использованием тестовых скрещиваний по схеме полных топкроссов и изучить корреляцию полученных эффектов ОКС с основными селекционными признаками.

Методика. Инбредные линии получали многократным инцухтом растений из гибридных популяций от скрещивания сортов ржи Альфа, Валдай, Восход 1, Восход 2, Саратовская 5, Безенчукская 87 и др. с различными донорами самофертильности. Линии отбирали по зимостойкости, короткому и прочному стеблю, продуктивности колоса, массе 1000 зерен, устойчивости к грибным болезням, числу падения и вязкости водного экстракта зернового шрота. Для создания стерильных аналогов инбредных линий в зимний период (в условиях теплицы) выполняли парные возвратные скрещивания, помещая под один пергаментный изолятор колосья стерильного и фертильного растений. Источником стерильной цитоплазмы типа Пампа была одна из высокостерильных инбредных линий. В теплице и в поле визуально контролировали сохранение стерильности у растений после каждого беккросса. 
При создании родительских линий А и В в формуле простого гибрида использовали различные генопулы, неродственные синтетику-опылителю С. Родителем А были пять мужски стерильных линий (Н-649, Н-577, Н-842, Н-1058 и Н-1185), выделившихся по комплексу хозяйственно ценных признаков (зимостойкости, короткостебельности, крупнозерности и др.). Тестовые скрещивания проводили в 2016 году на опытном поле Федерального исследовательского центра «Немчиновка» (Московская обл.) по схеме топкросса, используя в качестве отцовской формы четыре мужски фертильные линии (Н-451, Н-1011, Н-1247 и Н-1071). Полевые испытания полученных в итоге 20 межлинейных гибридов $\mathrm{F}_{1}$ провели в 2017 году на делянках 8,0 $\mathrm{M}^{2}$ в 3-кратной повторности при норме высева 500 зерен на 1 м $^{2}$. Уборку выполняли в фазу полной спелости (малогабаритный комбайн WinterClassic, «Wintersteiger AG», Австрия).

Эффекты ОКС и СКС материнских стерильных линий и отцовских фертильных тестеров оценивали с помощью математической модели, предложенной В.Г. Вольфом и П.П. Литуном (22).

Результаты. Погодные условия в период вегетации озимой ржи значительно отклонялись от нормы. В зимний период происходила частичная гибель растений из-за ледяной корки. Апрель был аномально холодным, в мае также преобладала холодная погода, часто выпадал снег с дождем, количество осадков оказалось рекордно высоким (88,4 мм при норме 52,4 мм). Сильные ливни в июне негативно повлияли на переопыление. В июле погода тоже в основном была холодной и влажной: количество осадков была на 34,6 \% больше нормы. Всего с апреля по июль при норме 249,5 мм выпало 420,3 мм осадков (168,5 \% от нормы). Это привело к полеганию некоторых гибридов, уменьшению массы 1000 зерен и как, следствие, снизило урожайность, технологические и хлебопекарные качества зерна.

Всего мы получили более 2000 гомозиготных линий, из которых отобрали лучшие по ряду признаков (зимостойкость, короткий и прочный стебель, раннеспелость, хорошо озерненный колос, крупное зерно, устойчивость к грибным болезням, высокое число падения и вязкость водного экстракта зернового шрота). На основе многолетних данных из этой группы выделили короткостебельные и ценные по комплексу других признаков инбредные линии, из них получили стерильные аналоги, которые использовали в «селекционном конвейере» по синтезу межлинейных гибридов $\mathrm{F}_{1}$ на основе ЦМС типа Пампа.

1. Урожайность (т/га) простых межлинейных гибридов $F_{1}$ озимой ржи (Secale cereale L.) (полевые испытания, Московская обл., 2017)

\begin{tabular}{|c|c|c|c|c|c|}
\hline \multirow{2}{*}{ Стерильная линия } & \multicolumn{4}{|c|}{ Фертильная линия (тестер) } & \multirow{2}{*}{ Среднее $X_{i}$} \\
\hline & $\mathrm{H}-451$ & $\mathrm{H}-1011$ & $\mathrm{H}-1247$ & H-1071 & \\
\hline H-649 & $7,02 *$ & $7,90^{*}$ & $7,03^{*}$ & 6,02 & 7,00 \\
\hline H-577 & 5,09 & 5,98 & 5,74 & 5,78 & 5,65 \\
\hline H-842 & 5,88 & 6,50 & 6,31 & 6,15 & 6,21 \\
\hline H-1058 & 6,89 & $7,03^{*}$ & 6,01 & 5,53 & 6,36 \\
\hline H-1185 & $7,39^{*}$ & $7,52^{*}$ & 6,89 & $7,19^{*}$ & 7,24 \\
\hline Среднее $X_{i}$ & 6,45 & 6,99 & 6,39 & 6,13 & 6,49 \\
\hline $\mathrm{HCP}_{05}$ & \multicolumn{4}{|c|}{0,52} & \\
\hline
\end{tabular}

Результаты полевого испытания 20 межлинейных гибридов $\mathrm{F}_{1}$ озимой ржи (табл. 1) показали, что их средняя урожайность в опыте составила 6,49 т/га (у популяционного сорта-стандарта Валдай 6,50 т/га). Семь гибридов $\mathrm{F}_{1}$ по конкурсному гетерозису достоверно $(\mathrm{P} \geq 0,95)$ превосходили этот стандарт на 0,5-1,4 т/га (на 8,0-21,5\%). Наибольшую урожайность имел гибрид $\mathrm{F}_{1}$ H-649 $\times$ H-1011 (7,90 т/га), наименьшую $-\mathrm{F}_{1} \mathrm{H}-577 \times \mathrm{H}-451$ 
(5,09 т/га). В родословной наиболее урожайных гибридов присутствовала материнская стерильная линия Н-1185, а среди отцов-тестеров - линия Н-1011. Гибриды с участием линий Н-577 и Н-842 оказались самыми низкоурожайными. Чаще всего высокоурожайные гибриды давали линии Н-1185, Н-649 и тестер Н-1011. Характерная особенность названных линий заключалась в том, что каждая из них дала по три высокоурожайных гибрида при скрещивании с другими. Это указывает на их высокую комбинационную ценность. В среднем частота гибридов $\mathrm{F}_{1}$ с достоверно повышенным конкурсным гетерозисом по урожайности составила $35 \%$ (7 из 20). При этом генотип материнских линий обусловил более сильное варьирование гибридов по урожайности, чем генотип линий-тестеров.

Варьирование урожайности у изучаемых гибридов в основном было обусловлено неодинаковой комбинационной способностью родителей. По результатам дисперсионного анализа в генотипической вариансе урожайности выделились три компоненты, существенно влияющие на дисперсию урожайности, - ОКС стерильных линий, ОКС тестеров и СКС комбинации линия $\times$ тестер (табл. 2).

2. Дисперсионный анализ комбинационной способности полученных инбредных линий озимой ржи (Secale cereale L.)

\begin{tabular}{l|c|r|r|r|r}
\hline \multicolumn{1}{c|}{ Источник дисперсии } & $\mathrm{SS}$ & $\mathrm{df}$ & $\mathrm{ms}^{2}$ & $\mathrm{~F}_{\text {факт. }}$ & $\mathrm{F}_{05}$ \\
\hline ОКС стерильных линий & 6,49 & 4 & 1,62 & 54,0 & 2,6 \\
ОКС линий-тестеров & 1,92 & 3 & 0,64 & 21,3 & 2,9 \\
СКС & 2,27 & 12 & 0,19 & 6,3 & 2,0 \\
Остаточная & 0,97 & 38 & 0,03 & &
\end{tabular}

П р и м е ч а н и е. ОКС - общая комбинационная способность, СКС - специфическая комбинационная способность.

Отметим относительно большую вариансу ОКС материнских стерильных линий $\left(\mathrm{ms}^{2}=1,62\right)$ и ОКС линий-тестеров $\left(\mathrm{ms}^{2}=0,64\right)$ в сравнении с вариансой СКС $\left(\mathrm{ms}^{2}=0,19\right)$. Суммируя дисперсии, получаем, что на долю эффектов ОКС приходится 91,1 \% всей изменчивости урожайности изучаемых гибридов, а на СКС - только 7,7 \%. Из этого следует, что основной компонент генотипической вариансы по признаку урожайности аддитивное взаимодействие генов, а не внутрилокусное доминирование. Большая величина соотношения варианс (OKC/CKC) указывает на достаточно высокую генетическую дивергенцию инбредных линий, взятых для скрещивания (23).

3. Эффекты общей и специфической комбинационно способности (ОКС и СКС) у полученных стерильных инбредных линий и фертильных линий-тестеров ржи (Secale cereale L.) (полевые испытания, Московская обл., 2017)

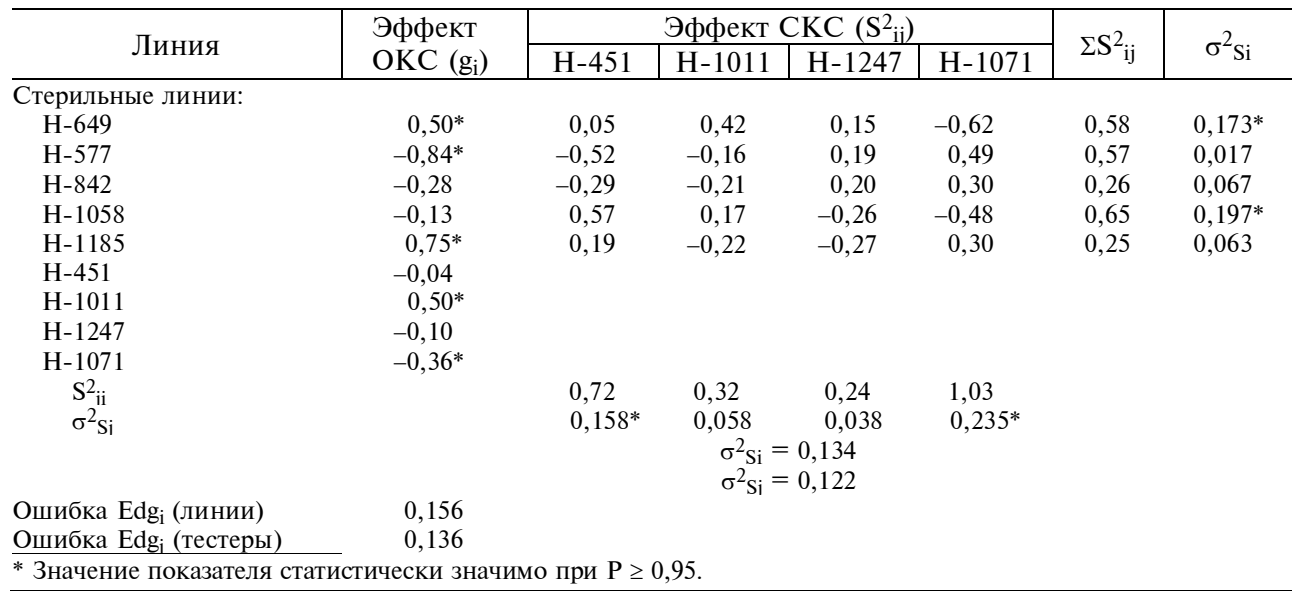


В наших опытах изучаемые линии имели как положительные, так и отрицательные оценки по ОКС. Стерильные линии Н-1185 и Н-649 характеризовались высокими эффектами ОКС по урожайности, короткостебельная линия Н-577 обладала существенно более низкой ОКС (табл. 3). Среди отцов-тестеров лучшей по ОКС была линия Н-1011, худшей - Н-1071 (см. табл. 3). Гибриды $\mathrm{F}_{1}$ с участием этих линий очень сильно варьировали по урожайности.

Используемая нами схема скрещиваний позволила сравнить линии не только по ОКС, но и по СКС и оценить вклад эффекта гетерозиса в потенциал урожайности для каждой пары родителей. Если величина гетерозиса в полученной комбинации значительно выше, чем можно ожидать на основании ОКС линии, то у такой линии высокая СКС. Показатель CКС позволяет определить, участие каких линий даст гибриды $\mathrm{F}_{1}$ с самой высокой урожайностью. Среди изученных нами линий значимо высокую СКС показали линии Н-649, Н-1058, Н-1071 и Н-451.

Следует учитывать, что при селекции инбредных линий важным ориентиром служит показатель их продуктивности. Т. Miedaner с соавт. (24), изучая связь между проявлением восьми признаков продуктивности у инбредных линий и у тесткроссов, пришли к выводу, что отбор линий per se на фенотипическом уровне важен на всех этапах гибридной селекции. Замечено, что по мере усложнения структуры признака генотипические корреляции $\left(r_{g}\right)$ становятся слабее. Самые высокие корреляции $\left(r_{g}>0,7\right)$ авторы выявили для высоты растения, массы 1000 зерен, а также числа падения и содержания крахмала (24). По нашим данным (табл. 4), стерильные линии Н-649 и Н-1185, а также фертильная линия-тестер Н-1011, показавшие наиболее высокие оценки по ОКС в сравнении с низкокомбинационной линией Н-577, выделялись относительно длинным стеблем (соответственно от 86 до 97 см против 78 см), более крупным зерном (масса 1000 зерен 24,4-30,0 г против 21,5 г) и продуктивным колосом (масса зерна с колоса 0,79-1,15 г против 0,62 г).

4. Проявление признаков продуктивности и их корреляция с эффектами общей комбинационной способности (OKC) у полученных стерильных инбредных линий и фертильных линий-тестеров ржи (Secale cereale L.) (полевые испытания, Московская обл., 2017)

\begin{tabular}{|c|c|c|c|c|c|c|c|}
\hline \multirow[b]{2}{*}{ Линия } & \multirow{2}{*}{$\begin{array}{l}\text { Эффект } \\
\text { ОКС }\end{array}$} & \multirow{2}{*}{$\begin{array}{l}\text { Высота рас- } \\
\text { тения, см }\end{array}$} & \multicolumn{2}{|c|}{ Macca, $\Gamma$} & \multicolumn{3}{|c|}{ Зерно и мука } \\
\hline & & & $\begin{array}{l}1000 \\
\text { зерен }\end{array}$ & $\begin{array}{l}\text { зерна } \\
\text { с колоса }\end{array}$ & $\begin{array}{l}\text { число па- } \\
\text { дения, с }\end{array}$ & $\begin{array}{l}\text { содержание } \\
\text { белка, \% }\end{array}$ & $\begin{array}{l}\text { вязкость водного } \\
\text { экстракта шрота, сП }\end{array}$ \\
\hline H-649 & 0,50 & 86 & 24,4 & 0,79 & 112 & 14,9 & 8,3 \\
\hline H-577 & $-0,84$ & 78 & 21,5 & 0,62 & 261 & 12,8 & 10,3 \\
\hline H-842 & $-0,28$ & 82 & 22,9 & 0,93 & 228 & 14,4 & 5,5 \\
\hline H- 1058 & $-0,13$ & 84 & 26,3 & 1,08 & 126 & 13,0 & 3,8 \\
\hline H-1185 & 0,75 & 95 & 29,5 & 1,15 & 234 & 12,8 & 8,5 \\
\hline H-451 & $-0,04$ & 81 & 22,8 & 0,73 & 265 & 14,3 & 3,6 \\
\hline H-1011 & 0,50 & 97 & 30,0 & 1,12 & 116 & 13,7 & 9,4 \\
\hline H-1247 & $-0,10$ & 80 & 22,8 & 0,63 & 222 & 13,1 & 6,2 \\
\hline H-1071 & $-0,36$ & 79 & 23,0 & 0,71 & 173 & 13,7 & 3,8 \\
\hline \multicolumn{8}{|c|}{ Коэффициент корреляции (r) эффекта ОКС с признаком: } \\
\hline & & $0,85^{*}$ & $0,80^{*}$ & $0,64 *$ & $-0,42$ & 0,20 & 0,23 \\
\hline
\end{tabular}

Мы выявили тесную связь между ОКС и некоторыми селекционно важными признаками. Так, проявилась высокодостоверная $(\mathrm{P} \geq 0,05)$ положительная корреляция между оценками ОКС линий и высотой растений $(r=0,85 \pm 0,10)$, массой 1000 зерен $(r=0,80 \pm 0,13)$ и массой зерна с колоса $(r=0,64 \pm 0,21)$. Важно отметить, что наличие сопряженности между ОКС и высотой растений нежелательно, так как длинностебельные ли- 
нии непригодны для гибридной селекции. Однако селекционное улучшение линий по этому признаку в принципе достижимо, особенно если применять интенсивную и масштабную селекцию на сочетаемость признаков крупнозерности и короткостебельности. Для этих признаков характерен высокий коэффициент наследуемости, поэтому отбор по ним per se среди используемых линий позволит более уверенно прогнозировать лучшие межлинейные гибриды. Возможность эффективного прогноза продуктивности простых межлинейных гибридов ржи по отдельным признакам родительских форм отмечают и другие исследователи $(25,26)$. По последним данным (3), в Германии в результате интенсивной селекции современные самоопыленные линии ржи превосходят по продуктивности первые инбредные формы в 5-8 раз, что соответствующим образом отразилось на продуктивности создаваемых коммерческих гибридов. Именно благодаря селекционному улучшению родительских форм современная гибридная рожь по урожайности достигла уровня таких ведущих зерновых культур, как кукуруза и пшеница.

Таким образом, по результатам полевого испытания 20 топкроссных гибридов $\mathrm{F}_{1}$ выделено 7 перспективных комбинаций, которые продемонстрировали достоверно высокий конкурсный гетерозис по урожайности. Наибольшую урожайность дал простой гибрид $\mathrm{F}_{1} \mathrm{H}-649 \times$ H-1011 (7,90 т/га, то есть с превышением на $21,5 \%$ относительно сорта-стандарта Валдай). Высокую общую комбинационную способность по урожайности также проявили стерильные линии Н-1185, Н-649 и тестер-опылитель Н-1011, следовательно, их можно эффективно вовлекать в гибридную селекцию. Наблюдаемое соотношение варианс ОКС/СКС указывает на значительную генетическую дивергенцию скрещиваемых инбредных линий. Эффекты ОКС положительно коррелировали с высотой растений, массой 1000 зерен и массой зерна с колоса. На основе корреляционного анализа сделано заключение о возможности раннего прогнозирования комбинационной способности инбредных линий ржи по сочетаемости крупнозерности и короткостебельности.

\section{ЛИТЕРАТУРА}

1. Geiger H.H., Schnell F.W. Cytoplasmic male sterility in rye (Secale cereale L.). Crop. Sci., 1970, 10(5): 590-593 (doi: 10.2135/cropsci1970.0011183X001000050043x).

2. Geiger H.H., Wilde P., Erfurt M., Pakas I. Heterosis of factorial inter-pool single crosses among elite winter rye inbred lines. Proc. EUCARPIA Rye Meeting (Juli 4-7, 2001, Radzikow, Poland). Radzikow, 2001: 19.

3. Wilde P., Bajgain P., Dopierala P., Gordillo A., Korzun V., Menzel J., Schmiedchen B., Steffan P. Genetic gain from hybrid rye breeding: achievements and challenges. Proc. EUCARPIA Cereals Section Conference 2015. Int. Conf. on Rye Breeding and Genetics (June 24-26, 2015, Wroclaw, Poland). Wroclaw, 2015: 20-21 (doi: 10.5281/zenodo.1288518).

4. Laidig F., Piepho H.-P., Rentel D., Drobek T., Meyer U., Huesken A. Breeding progress, variation and correlation of grain and quality traits in winter rye hybrid and population varieties and national on-farm progress in Germany over 26 years. Theor. Appl. Genet., 2017, 130(5): 981-998 (doi: 10.1007/s00122-017-2865-9).

5. Miedaner T. Roggen. DLG-Verlag, Franrfurt/Main, 1997.

6. Geiger H.H., Miedaner T. Rye breeding. In: Cereals (Handbook of Plant Breeding) /M.J. Carena (ed.). Springer Science + Business Media LLC, 2009: 157-182.

7. Banaszak Z., Banaszak K., Kaczmarek K. Rye varieties in Poland. Proc. EUCARPIA Cereals Section Conference 2015. Int. Conf. on Rye Breeding and Genetics (June 24-26, 2015, Wroclaw, Poland). Wroclaw, 2015: 23-24 (doi: 10.5281/zenodo.1288518).

8. Larsen R.J. Historical, current and potential future trends for rye production and breeding in Canada. Proc. EUCARPIA Cereals Section Conference 2015. Int. Conf. on Rye Breeding and Genetics (June 24-26, 2015, Wroclaw, Poland). Wroclaw, 2015: 21 (doi: 10.5281/zenodo.1288518).

9. Гончаренко А.А. Актуальные вопросы селекции озимой ржи. М., 2014.

10. Geiger H.H. Hybrid breeding in diploid rye. Proc. EUCARPIA Meeting of the Cereal Section on 
Rye (June 11-13th 1985, Svalöv, Sweden). Svalov, 1985: 237-265.

11. Деревянко В.П., Егоров Д.К. Актуальные вопросы гетерозисной селекции озимой ржи. Харьков, 2008.

12. Лапиков Н.С., Кобылянский В.Д., Катерова А.Г. Результаты создания исходного материала для селекции гибридной ржи. В сб.: Генетические ресурсы культурных растений. СПб, 2001: 333-335.

13. Miedaner T., Muller B.U., Piepho H.-P., Falke K.C. Genetic architecture of plant height in winter rye introgression libraries. Plant Breeding, 2011, 130(2): 209-216 (doi: 10.1111/j.14390523.2010.01823.x).

14. Гончаренко А.А., Ермаков С.А., Макаров А.В., Семенова Т.В., Точилин В.Н., Крахмалева О.А. Оценка комбинационной способности инбредных линий в топкроссных скрещиваниях. Достижения науки и техники АПК, 2016, 9: 19-22.

15. Соколов Б.П., Костюченко В.И. К вопросу выбора тестеров для оценки комбинационной способности линий кукурузы в топкроссах. Сельскохозяйственная биология, 1978, 13(1): 44-48.

16. Бондарь В.Т. Комбинационная способность самоопыленных линий озимой ржи. В сб.: Селекция и семеноводство. Киев, 1973, вып. 24: 3-8.

17. Tomerius A.-M., Miedaner T., Geiger H.H. A model calculation approach towards the optimization of a standart scheme of seed-parent line development in hybrid rye breeding. Plant Breeding, 2008, 127(5): 433-440 (doi: 10.1111/j.1439-0523.2008.01493.x).

18. Miedaner T., Geiger H.H. Estimates of combining ability for resistance of winter rye to Fusarium culmorum head blight. Euphytica, 1996, 89(3): 339-344 (doi: 10.1007/BF00022290).

19. Oettler G., Heinrich N., Miedaner T. Estimates of additive and dominance effects for Fusarium head blight resistance of winter triticale. Plant Breeding, 2004, 123(6): 525-530 (doi: 10.1111/j.1439-0523.2004.01010.x).

20. Reif J.C., Hahn V., Melchinger A.E. Genetic basis of heterosis and prediction of hybrid performance. Helia, 2012, 35(57): 1-8 (doi: 10.2298/hel1257001r).

21. Smith O.S. Covariance between line per se and testcross performance. Crop Sci., 1986, 26(3): 540-543 (doi: 10.2135/cropsci1986.0011183X002600030023x).

22. Вольф В.Г., Литун П.П. Методические рекомендации по применению математических методов для анализа экспериментальных данных по изучению комбинационной способности. Харьков, 1980.

23. Fischer S., Mohring J., Schon C.C., Piepho H.-P., Klein D., Schipprack W., Utz H.F., Melchinger A.E., Reif J.C. Trends in genetic variance components during 30 years of hybrids maize breeding at the University of Hohenheim. Plant Breeding, 2008, 127(5): 446-451 (doi: 10.1111/j.1439-0523.2007.01475.x).

24. Miedaner T., Schwegler D.D., Wilde P., Reif J.C. Association between line per se and testcross performance for eight agronomic and quality traits in winter rye. Theor. Appl. Genet., 2014, 127(1): 33-41 (doi: 10.1007/s00122-013-2198-2).

25. Geiger H.H., Miedaner T. Hybrid rye and heterosis. In: The genetics and exploration of heterosis in crops. ASA-CSSA-SSSA, Madison, USA, 1999: 439-450.

26. Kolasinska I. Heterosis of interlinear rye hybrids. Aufgaben und Entwicklungstendenzen der Roggen Forschung und Roggenzüchtung, 1982, 198: 341-347.

ФГБНУ ФИЦ «Немчиновка»,

143026 Россия, Московская обл., Одинцовский р-н, пос. Новоивановское, ул. Агрохимиков, 6,

e-mail: goncharenko05@mail.ru $\varangle$, mak.alex65@mail.ru,

ermakov.rozh@yandex.ru, mosniish@yandex.ru, val.tochilin@yandex.ru,

tzugnatali@yandex.ru, olga.krahmaleva@yandex.ru
Поступила в редакцию 26 июня 2018 года

\section{SELECTION OF WINTER RYE (Secale cereale L.) INBRED LINES FOR GENERAL AND SPECIFIC COMBINING ABILITY AND ITS RELATIONSHIP WITH VALUABLE TRAITS}

\section{A.A. Goncharenko, A.V. Makarov, S.A. Ermakov, T.V. Semenova, V.N. Tochilin, N.V. Tsygankova, O.A. Krahmaleva}

Federal Research Center Nemchinovka, 6, ul. Agrochimikov, pos. Novoivanovskoe, Odintsovo Region, Moscow Province, 143026 Russia, e-mail goncharenko05@mail.ru ( $₫$ corresponding author), mak.alex65@mail.ru, ermakov.rozh@yandex.ru, mosniish@yandex.ru, val.tochilin@yandex.ru, tzugnatali@yandex.ru, olga.krahmaleva@yandex.ru ORCID:

Goncharenko A.A. orcid.org/0000-0002-5532-3179 Makarov A.V. orcid.org/0000-0003-0939-992X
Tochilin V.N. orcid.org/0000-0003-0691-8413

Tsygankova N.V. orcid.org/0000-0002-6797-5377 
The authors declare no conflict of interests

Acknowledgements:

Supported financially by Russian Foundation for Basic Research, project No. 17-44-500827

Received June 26, 2018

doi: 10.15389/agrobiology.2019.1.38eng

Creation of $\mathrm{F}_{1}$ heterosis hybrids instead of population varieties is an advanced breeding technology since XX century. The rye as a strictly cross-pollinated culture is rather perspective for heterotic breeding. The success depends on the use of rye homozygous lines with high combining ability. The topcrossing allows effective estimates of the best genotypes to be used in synthesis of high heterotic hybrids. This paper is the first characterization of the authors' winter rye unique high-homozygous inbred lines, which are based on three Russian gene pools, with high combining ability intended for breeding programs. The purpose of our researches was to estimate by topcrossing method the general and specific combining ability of winter rye inbred lines. Test crossings in 2016 involved five sterile lines with type Pampas cytoplasm (H-649, H-577, H-842, H-1058, and H-1185), and four male fertile lines $(\mathrm{H}-451, \mathrm{H}-1011, \mathrm{H}-1247$, and $\mathrm{H}-1071)$ as testers. In total, 20 simple $\mathrm{F}_{1}$ interlinear hybrids were selected. In 2017 , the hybrids were studied in plot tests $\left(8 \mathrm{~m}^{2}\right.$ plots, 3 replications, and 500 grains per $\left.1 \mathrm{~m}^{2}\right) . \mathrm{F}_{1}$ hybrid yields varied from 5.02 up to $7.90 \mathrm{t} /$ ha vs. $6.50 \mathrm{t} /$ ha yield of population variety Valdai. The highest yield had $\mathrm{F}_{1}(\mathrm{H}-649 \times \mathrm{H}-1011$, i.e. $7.9 \mathrm{t} /$ ha that is $21.5 \%$ higher compared to the standard Valdai variety. As a whole, the frequency of $F_{1}$ hybrids with high competitive heterosis is 7 of 20 (or $35 \%$ ). Variation of $F_{1}$ productivity is mainly due to different combining ability of their parents. Note, both general and specific combining abilities (GCA and SCA) contribute to a dispersion of productivity trait, thought GCA effects account to $91.1 \%$ while SCA only 7.7 $\%$. Thence, additive gene effects but not intralocus dominance are the basic genotypic components of productivity trait variance. The obtained GCA/SCA values specify on high enough genetic divergence of the inbred lines used. Sterile analogues of lines H-1185 and H-649, and also of paternal line-tester H-1011 possess high GCA effects. The dwarf lines H-577 and H-1071 show lower general combining ability. High SCA effects are characteristic of the sterile lines H-1058 and H-649, and also the testers $\mathrm{H}-1071$ and $\mathrm{H}-451$. It was revealed that GCA of the used rye lines positively correlates with plant height $(r=0.85 \pm 0.10), 1000$-grain weight $(r=0.80 \pm 0.13)$ and grain weight per ear $(r=$ $0.64 \pm 0.21)$. These data emphasize the importance of inbred lines' selection for high own performance and combining of high 1000-grain weight and a dwarfism.

Keywords: Secale cereale L., winter rye, cytoplasmic male sterility, CMS, tester, homozygous inbred line, $F_{1}$ hybrids, general combining ability, GCA, specific combining ability (SCA), yield, 1000-grain weight, grain weight per ear, dwarfism.

\section{Научные собрания \\ V МЕЖДУНАРОДНАЯ НАУЧНО-ПРАКТИЧЕСКАЯ КОНФЕРЕНЦИЯ «БИОЛОГИЧЕСКИЕ И ЭКОЛОГИЧЕСКИЕ ОСНОВЫ СЕЛЕКЦИИ, СЕМЕНОВОДСТВА И РАЗМНОЖЕНИЯ РАСТЕНИЙ»}

(проводится под эгидой Отделения сельскохозяйственных наук РАН)

(2-7 сентября 2019 года, г. Ялта, Республика Крым, НБС-ННЦ)

\section{Тематические направления:}

- Генетические основы гибридизации, гетерозиса, мутагенеза, методов восстановления генотипического потенциала сортов и гибридов в процессе стабилизирующей селекции (первичное семеноводство) полевых, овощных, садовых и лесных древесных растений

- Биотехнологические основы селекции, размножения и оздоровления растений

- Инновационные положения учения о связи генотипа и среды; управление экспрессией генов

- Физиологические и биохимические основы селекции, размножения и технологий выращивания семян и посадочного материала

- Биологические и экологические основы повышения устойчивости растений к неблагоприятным факторам среды в процессе селекции и размножения растений

- Теоретические и методологические основы зонального семеноводства полевых, овощных, садовых и лесных древесных растений

- Совершенствование методов оценки, стандартизации, сертификации семян и посадочного материала и их интеграция в международные системы

- Современные проблемы маркетинга и менеджмента в области селекции и семеноводства в новых экономических условиях

Контакты и информация: e-mail: makruschin-nm@ukr.net, sbornik2019@rambler.ru 